\title{
Poor Governance in Egypt, an Obstacle to Economic Development
}

\author{
Dr Taha Kassem \\ Assistant Professor in Political Economy College of Management and Technology Arab Academy for Science, \\ Technology and Maritime Transport Egypt
}

\begin{abstract}
Good governance is a prerequisite for a high level of economic development, while poor or bad governance results in a low level of economic development. Egypt as a case study represents an obvious example of the later. This paper aims at clarifying the correlation between the type of governance and the level of economic development. First, this paper starts with an introduction which briefly identifies the aim of the paper, the nature of governance and the adopted school of thought concerning the relation between governance and economic development. Second, it sheds light on the World Bank indicators of governance and their application on Egypt and the type of governance which Egypt witnessed during the rule of Mubarak and his predecessors .Third, it clarifies the impact of governance in Egypt on the economic development aspects. Finally, it concludes with some concluding remarks.
\end{abstract}

Keywords: economic development- elements of good governance- grand and petty corruption- the governance for growth theory- national integrity system

\section{Introduction}

Good governance is an essential complement to sound economic policies. Efficient and accountable management by the public sector and a predictable and transparent policy framework are critical to the efficiency of markets and governments, and hence to economic development. ${ }^{1}$ Under the rule of ex-president Hosni Mubarak and his predecessors, the Supreme Council of the Armed forces (SCAF) and the rule of the Muslim Brotherhood led by the former president Mohamed Morsi Egypt witnessed and suffered from bad governance which negatively affected and contributed to lower economic development level. International Reports indicate that accountability mechanisms are missing in Egyptian government performance. Consequently there exist multiples of modes of corruption such as misuse of public funds, bribes, tax fraud, misuse of power and authority, favoritism and ascription in selecting government leaders and in providing government services. Moreover the bureaucratic establishment suffers from massiveness and rigidity that frequently hinders attempts of modernization and improvement, and thus, the executive authority is severely centralized.

The concept of "governance" is not new. It is as old as human civilization. Simply put "governance" means: the process of decision-making and the process by which decisions are implemented (or not implemented). ${ }^{2}$ In the 1992 report entitled "Governance and Development", the World Bank set out its definition of good governance. This term is defined as "the manner in which power is exercised in the management of a country's economic and social resources for development". ${ }^{3}$ Sustainable development can only take place if a predictable and transparent framework of rules and institutions exists for the conduct of private and public business. The essence of good governance was described as predictable, open and enlightened policy, together with a bureaucracy imbued with a professional ethos and an executive arm of government accountable for its actions. All these elements are present in a strong civil society participating in public affairs, where all members of the society act under the rule of law. In analyzing governance, the World Bank drew a clear distinction between the concept's political and economic dimensions. ${ }^{4}$ As the World Bank's mandate is the promotion of sustainable development, its call for good governance exclusively concerns the contribution the concept makes generally to social and economicdevelopment and specifically to the World Bank's fundamental objective of sustainable poverty reduction in the developing world. The World Bank identified three distinct aspects of governance:

(a) The form of the political regime;

\footnotetext{
${ }^{1}$ World Bank Report, 1992, Governance and Development

${ }^{2}$ United Nations Economic and Social Commission for Asia and the Pacific, What is Good Governance

${ }^{3}$ Ibid, World Bank Report, 1992

${ }^{4}$ IFAD,INTERNATIONAL FUND FOR AGRICULTURAL DEVELOPMENT, Executive Board - Sixty-Seventh Session,September 1999,GOOD GOVERNANCE: AN OVERVIEW, p. 1
} 
(b) The process by which authority is exercised in the management of a country's economic and social resources for development; and

(c) The capacity of governments to design, formulate and implement policies and discharge functions.

The first aspect is deemed to be outside the World Bank's mandate, thus its focus has been on the second and third aspects. ${ }^{5}$ In the 1994 report entitled "Governance: The World Bank's Experience", the recent progress made by the Bank in this area is set out under four different aspects, which provide a template against which its governance work can be assessed:

(a) Public-sector management. This is the most readily identified dimension of the World Bank's governance work. The language of public-sector management is predominantly technical, changing the organizational structure of a sector agency to reflect new objectives, making budgets work better, sharpening civil-service objectives and placing public-enterprise managers under performance contracts.

(b) Accountability. Governments and their employees should be held responsible for their actions.

(c) Legal framework for development. Appropriate legal systems should be created those provide stability and predictability, which are the essential elements in creating an economic environment in which business risks may be rationally assessed.

(d) Transparency and information. The themes of transparency and information pervade good governance and reinforce accountability. Access to information for the various players in the market is essential to a competitive market economy. ${ }^{6}$

Supporting the World Bank perspective, this paper adopts the governance for growth theory as distinguished from the successful society and the social order theories. There are several theories of governance and development emanating from various disciplines in the social sciences, as well as from interdisciplinary perspectives.The three main economic schools of thought on the role of governance in development are: (1) the 'successful society'; ${ }^{7}$ (2) the governance for growth theory, and (3) the 'social order' theory. ${ }^{8}$ The governance for growth theory emerged from research that showed a link between good governance and economic growth, which is countries with 'good' governance have higher rates of economic growth in comparison to those with poor governance. Indeed, for many economists and political economists, therefore, the main theories of governance and development are found in the interpretation of the dynamics of the relationship between governance and economic growth. Furthermore, not only are growth and increases in per capita income viewed by some academics as the raison d'etre of development, but enhanced governance is viewed to be at the heart of

\footnotetext{
Ibid, p. 1

${ }^{6}$ World Bank Report, 1994, Governance, The World Bank Experience.

${ }^{7}$ Bloom, D., Steven, D. \& Weston, M. (2004) Governance matters: the role of governance in Asian economic development.World Economics, 5, 4, pp. 53-78. The first school of thought centers around shaping the governance and development agenda with a focus on key features and characteristics of a 'successful society' - in other words, what key aspects of governance in developed countries should be mimicked, emulated or adapted by developing countries. Bloom et al.'s (2004) survey of the major theories of governance with respect to economic development (and with special reference to Asian countries) suggests that the successful society possesses the following key characteristics in terms of 'good governance' and exemplary economic development: (1) competitiveness - that is, the successful nation is competitive, and one of the main issues in this respect is the various ways that governments can facilitate the competitiveness of firms and industries; (2) strong institutions and rules-based conduct - as effective, adaptable, stable rules-based and accountable institutions are crucial for successful development; and (3) social capital - for actions to facilitate competitiveness and build strong institutions occur within a social context. Furthermore, these pivotal aspects of governance require three conditions to facilitate economic development: clear definition of roles for institutions and other players; responsiveness of governance arrangements to existing conditions, plus adaptability to change; and a consistent focus on the public interest. Importantly, this way of thinking about governance and development also results in the pursuit of broad-based governance interventions or reform.

${ }^{8}$ North, D., Wallis, J. \&Weingast, B. (2008) Violence and social orders: a conceptual framework for interpreting recorded human history. Governance, Growth andDevelopment Decision-making. Washington, DC: World Bank.The third school of thought - and perhaps the most creative, robust and interesting theory on the overall subject - is provided by North et al. (2008). They divide the world's 200 countries into two parts: 175 countries with $85 \%$ of the world's population have a social order that first appeared about ten millennia ago, and exists to this day in various forms or stages that are part of the 'natural state' (which replaced the primitive or first social order). The remaining 25 countries, representing about $15 \%$ of the global population, are characterized by the third social order, which first emerged in a few societies at the end of the eighteenth and beginning of the nineteenth centuries - the 'open access' society. There are at least three other key points to the thesis presented by North et al. (2008). First, social order is maintained through the interplay between competition, institutions and beliefs. Second, with respect to the transition to open access, the historical and institutional context is important, but the specific details of change and the specific institutions that are the agents of change differ across societies. Therefore, they believe that modern economics fails to understand that interventions and proposed reforms supported by international organisations must conform to existing beliefs about economic, social and cultural systems in the natural state (i.e. the developing country) to be appropriate and successful. Failure to recognise this produces new institutional forms that are less effective than the ones they replace; and specifically because the broad prescriptions that mimic the open access orders are prescribed, including less regulatory control, absence of monopolies, more secure property rights and improved provision of public goods such as education, and more complete markets (North et al. 2008). Third, institutions and organisations help to reduce the threat of violence and disorder. It is these key insights that are central to this thesis on governance, development and
} social order. 
the development puzzle. ${ }^{9}$ One leading academiceconomist has even declared that 'good governance is development itself; combine it with material well-being, and we attain the Nirvana ofadvanced societies ${ }^{10}$

\section{Indicators of Governance}

Although the neoliberal ideology gradually emerged in the late 1980s and early 1990s, with its good governance and free-market agenda, the first clear official policy shift on governance matters in international development was announced in 1996 through a seminal address at the Annual Meeting of the World Bank and the International Monetary Fund (IM F), which placed good governance and tackling corruption as priority issues (World Bank 1996). ${ }^{11}$ The World Bank (2006a, 2007), for example, argues that a large body of research shows that, in thelong term, enhanced governance is associated with a broad scope of indicatorsof developmental progress. ${ }^{12}$ This stance is generally also advancedby all international organizations with reference to research findings anddiscussion (policy-driven, academic, empirical and anecdotal) on specificaspects of governance. For example, good economic management and aidcontribute to growth; fiscal decentralization canpromote enhanced governance; and reforming public institutionscan strengthen governance .Thus, enhancedgovernance is suggested to be at the heart of economic, social and politicalprogress. ${ }^{13}$

Most scholars, policymakers, aid donors, and aid recipients recognize that good governance is a fundamental ingredient of sustained economic development. Thisgrowing understanding, which was initially informed by a very limited set of empiricalmeasures of governance, has spurred an intense interest in developing more refined,nuanced, and policy-relevant indicators of governance. However, there is a question which arises in this context: "What do we measure?"

We highlight the distinction between indicators that measure the existence of specific laws or rules 'on the books', and indicators that measure particulargovernance outcomes 'on the ground; the former codifies details of the constitutional,legal or regulatory environment, the existence or absence of specific agencies such asanticorruption commissions or independent auditors, etc., that are intended to providethe key de jure foundations of governance. The latter are indicators that measure defacto governance outcomes that result from the of the application of these rules: forexample, do firms find the regulatory environment cumbersome?, do households believethe police are corrupt?, etc. ${ }^{14}$

\subsection{Rules-Based Indicators of Governance (De Jure Foundations of Governance)}

Under the rules-based indicators we can measure whether countries have legislation that prohibits corruption, or whether ananticorruption agency exists. Concerning the case of Egypt, bribery and corruption are dealt with primarily under the Egyptian Penal Code, which addresses bribery in both the public and private sectors. Egypt ratified the UN Convention against Corruption in 2005, but is not party to the OECD Convention onBribery of Foreign Public Officials in International Business Transactions or the African Union Convention on Preventing and Combating Corruption. Anti-bribery provisions in Egypt are contained primarily in the Egyptian Penal Code, which contains stringent criminal sanctions applicable to bribery of a government employee for the purpose of the performance (or lack of performance) of his or her duties. Less severe penalties apply for bribery of a private employee. Egypt does not have legislation that explicitly prohibits the bribery of foreign government officials. Legislation in Egypt does not extend to criminal acts committed abroad, except in the event that an Egyptian citizen commits an act abroad, which constitutes a crime both in that country and in Egypt. Egyptians who commit crimes related to bribery outside of Egypt may be subject to the penal sanctions relating to bribery crimes under the Egyptian Penal Code upon return to Egypt, unless he or she has undergone trial for that offense in the other jurisdiction.

Several Egyptian laws contain provisions applicable in the context of corruption and bribery. The main offenses are outlined in the Egyptian Penal Code, first passed in 1937 and amended subsequently. Articles 103 to 125 deal with bribery, embezzlement of public funds, and abuse of position and authority. These provisions include

\footnotetext{
${ }^{9}$ Knack, S. \& Keefer, P. (1995) Institutions and economic performance: cross-country tests using alternative institutional measures. Economics and Politics, 7, 3, pp. 207-227.

${ }^{10}$ Rodrik, D. (2008) Thinking about governance. Governance, Growth and Development Decision-makingWashington, DC: World Bank.

${ }^{11}$ Chibba, Michael, 2009, Governance and Development, The current role of theory, policy and practice, WORLD ECONOMICS • Vol. 10 • No. 2, p. 80

${ }^{12}$ World Bank (2006a) Strengthening Bank Group Engagement on Governance and Anti-Corruption, Washington, DC: World Bank (17 August).

World Bank (2006b) Press Release: World Bank Releases Largest Available Governance Data Source. Press Release No. 2009/63/WBI. Washington, DC: World Bank.

World Bank (2007) Global Monitoring Report 2006. Washington, DC: World Bank.

${ }^{13}$ Chibba, Michael Ibid, p. 84. Also look at: Burnside, C. \& Dollar, D. (1998) Aid, the incentive regime and poverty reduction. Policy Research Working Paper No. 1937. Washington, DC: World Bank.,Huther, J. \& Shah, A. (1998) Applying a simple measure of good governance to the debate on fiscal decentralization. Policy Research Working Paper No. 1894. Washington, DC: World Bank and Rodrik, D. (2007) One Economics, Many Recipes: Globalization, Institutions, and Economic Growth. Princeton, NJ: Princeton University Press. ${ }^{14}$ Kaufmann, Daniel, Kraay, Aart, 2008,World Bank Research Observer Volume 23, Issue 1 Pages: 1 - 30
} 
making it an offence for a public employee to request, or accept for him/herself or others, a gratuity or promise for the purpose of performing his professional duties or for refraining from performing a duty. It is an offence to request or accept rewards of any kind or for a public employee to perform or refrain from performing a professional duty as a result of any personal requests, recommendations, connections, or undue influence. Recipients, intermediaries and providers of bribes are equally liable, but providers and intermediaries can be exempted from punishment if they inform the authorities of the offense or confess to it. Article 109 provides that anyone who offers a bribe to a public employee even if not accepted, is guilty of a bribery offense, and it is an offence for anyone to accept or offer to be an intermediate in a bribe, even if the act does not extend beyond the offer or acceptance. Public employees can be sentence to terms of imprisonment of between three and fifteen years for bribery offences. ${ }^{15}$

In 2007, the Egyptian government established several institutions to combat corruption. The Minister of State for Administrative Development set up the Transparency and Integrity Committee (TIC) to study and recommend means and mechanisms of enhancing transparency, accountability, and the fight against corruption at central and local government levels. The Ministry of Investment in turn established a Transparency Unit, supported by the UNDP, whose task is to improve the investment climate through legislativeamendments that strengthen freedom of information and transparency, raise public awareness and stakeholder engagement, and build capacity and knowledge management. Egypt has also joined a number of international initiatives and projects to combat corruption. They include the MENA-OECD Task Force on Anti-Bribery, the OECD Good Governance for Development in Arab Countries Initiative, the Arab Anti-Corruption and Integrity Network (ACINET), and the UNDP-POGAR project to support the Ministry of Investment in the fight against corruption. Egypt is also a signatory to the UN Convention against corruption (UNCAC, 2003). UNCAC is the first legally binding international anti-corruption instrument. It obliges States to implement a wide and detailed range of anti-corruption measures affecting their laws, institutions and practices. These measures aim to promote the prevention, criminalization and law enforcement, international cooperation, asset recovery, technical assistance and information exchange, and mechanisms for implementation.

The UNCAC was adopted by the United Nations General Assembly in October 2003 and signed by 140 countries. As of 13 December 2011, the convention had been ratified, accepted, approved or acceded to by 158 countries (which became thus States Parties to the convention) as well as the EU and applies to most of the world population. ${ }^{16}$

The preventive measures set out in the Convention cover both the public and private sectors. Key requirements include:

The establishment of anti-corruption bodies;

$>$ Enhanced transparency in the financing of election campaigns and political parties.

$>$ Anti-corruption bodies should implement the anti-corruption policies, disseminate knowledge and must be independent, adequately resourced and have properly trained staff;

$>$ States are also obliged to ensure that their public services are subject to safeguards that promote efficiency, transparency and recruitment based on merit;

$>$ Public servants should be bound by codes of conduct, requirements for financial and other disclosures, and appropriate disciplinary measures;

$>$ It requires measures to prevent money laundering;

$>$ Transparency and accountability in matters of public finance must also be promoted,

$>$ Specific requirements are established for the prevention of corruption, in the particularly critical areas of the public sector, such as the judiciary and public procurement;

$>$ Since the combating of corruption also depends on cooperation between the State and society, the UNCAC places particular emphasis on the involvement of civil society and on the general reporting process through which the public administration reports to the people;

$>$ The requirements made for the public sector also apply to the private sector - it too is expected to adopt transparent procedures and codes of conduct.

In addition, at the international level, there is an African Union Convention on Preventing and Combating Corruption. It aims to promote mechanisms to fight corruption in the public and private sectors, to facilitate cooperation among states parties, and to coordinate the policies and legislation relevant to corruption. The Convention's scope is broad and covers active and passive bribery, influence peddling, illicit enrichment, concealment of proceeds derived from corrupt acts. Its requirements are extensive and appear to be binding. It is not yet in force. ${ }^{17}$

In summary then, there are adequate laws against corruption, international treaties have been ratified, anti-corruption bodies established. Notwithstanding all of this, reality tells us that corruption is still perceived to

\footnotetext{
${ }^{15}$ Puddephatt,Andrew, (2012), Corruption in Egypt, Global Partners \& Associates, pp. 6-7.

${ }^{16}$ Ibid, pp8-9.

${ }^{17}$ Ibid, p.9
} 
be a major problem in Egypt. Though the evidence is usually anecdotal and based on perceptions, the weight is considerable.In 2010, Transparency International's Corruption Perceptions Index report assessed Egypt with a CPI score of 3.1, based on perceptions of the degree of corruption from business people and country analysts, with 10 being very clean and 0 being highly corrupt. Egypt ranked 98th out of the 178 countries included in the report. This low score implies a high level of corruption in Egypt. ${ }^{18}$ Surveys of Egyptian public opinion are more nuanced. A 2009 survey of public opinion sought to identify who had direct experience of corruption, and found that just 14 per cent of the urban population and 7 per cent of the rural population had such experiences. ${ }^{19}$ Between two and four per cent said yes which implies that low level transactional corruption is not so common (despite public perceptions to the contrary). By contrast, 42 per cent of small business owners surveyed in CIPE's 2009 survey of 797 small and medium enterprises (SMEs) indicated that they had been obliged to offer illegal payments or gifts to obtain their business licenses. In addition 29 per cent had to pay bribes during the course of the operation of their business. ${ }^{20} \mathrm{When}$ asked about the reasons for these payments, it was surprising that a full 90 per cent of those who said they had paid bribes regarded it as something normal, 'something everybody does'. Many were obliged to make these payments with 56 per cent of those surveyed stating that the civil servant requested a bribe directly. 70 per cent indicated they paid bribes to receive expedited service. This suggests that delaying transactions is a means for civil servants to persuade citizens to make these illegal payments. In addition, 27 per cent mentioned they made illegal payments so that the civil servant would process the transaction despite missing or improperly filled-out paperwork. ${ }^{21}$ However, only a small percentage of respondents' perceptions of corruption are based on direct experience - overall ten per cent indicated that they have paid bribes. Most Egyptians' opinions about corruption are shaped by rumors, discussions among family and friends or from stories in the media, of which satellite television channels are the most influential. Businesses have long complained about corruption in Egypt and the hazards of doing business in such a climate. A survey by Enterprise Surveys, however, showed that corruption, though serious, was not the major concern for companies. ${ }^{22}$

\subsection{Outcome-Based Governance Indicators (De Facto Governance Outcomes)}

The outcome-based governance indicators measure whether in practice the laws regarding corruption are enforced or whether the anticorruption agency is undermined by political interference. On the governmental sector, anti-corruption concepts, such as integrity, transparency, and accountability, are poorly understood by public sector officials, private companies and the citizenry alike in Egypt, posing a challenge to the fight against corruption. Government officials often have difficulty in grasping these concepts and finding ways to make them part of their oversight practices.On the other hand, non-government perception surveys report that corruption is widespread and that it is part of daily life. Corruption allegations are frequent in the media and people often speak of the practice as affecting all parts of society. The phenomenon results in part from and builds on the fact that a very large part of the Egyptian economy is informal (around 35per cent by some estimates. ${ }^{23} \mathrm{~A}$ recent Global Financial Integrity report claimed that crime and corruption cost Egypt approximately US\$ 6 billion per year and US\$ 57.2 billion total, from 2000-2008; much of this money, the report authors' note, was driven out by personal tax evasion, in addition to corruption and crime. ${ }^{24}$ Egypt appears to be confronted with both grand and petty corruption. Corporate surveys testify that corruption is a major obstacle to business operations and growth in Egypt. International organizations, too, have persistently pointed to the seriousness of the problem. ${ }^{25}$ On a cautionary note there is no accurate data about corruption. While there is a widespread assumption about levels of corruption - particularly among the leaders of the Mubarak regime there is little concrete evidence or reliable data to depend upon. For this report $\mathrm{w}$ a number of interviews were conducted with senior Egyptian figures from the worlds of government, business and universities. Their perceptions of corruption under a number of headings were clear. ${ }^{26}$ All emphasized the lack of reliable data. Ahmed Ghoneim, Professor of Economics at Cairo University, said: "Corruption is high, but there is no concrete

\footnotetext{
${ }^{18}$ Transparency International, 2010. Corruption Perceptions Index 2010 Results, [online] http://www.transparency.org/policy_research/surveys_indices/cpi/2010/results ${ }^{19}$ CIPE, 2010. Egyptian Citizens' Perceptions on Transparency and Corruption

${ }^{20} \mathrm{CIPE}$ and Al-Ahram Centre for Political and Strategic Studies, 2009. Business Environment for Small and Medium-Sized Enterprises (SME) in Egypt and SMEs' Interaction with Government Agencies: 2009 Survey on Corruption, [online] http://www.cipe.org/sites/default/files/publication docs/2009\%20Egypt\%20SME\%20Survey\%20Report\%20EN_0.pdf ${ }^{21}$ Ibid.

${ }^{22}$ Enterprise Surveys, 2008. Egypt, Arab Rep., [online] http://www.enterprisesurveys.org/Data/ExploreEconomies/2008/egypt\#corruption

${ }^{23} \mathrm{OECD}, 2010$. Business Climate Development Strategy, Egypt: Policies for Better Business Regulation, [online] http://www.oecd.org/dataoecd/49/20/46341268.pdf

${ }^{24}$ Task Force for Financial Integrity \& Economic Development, 2011. Egypt Lost \$57.2 Billion From 2000-2008, [online] http://www.financialtaskforce.org/2011/01/26/egypt-lost-57-2-billion-from-2000-2008/

${ }^{25}$ OECD, 2010.Ibid.

${ }^{26}$ Puddephatt, Andrew, ibid, p. 12
} 
data. It is something you can feel and it is spoken about. With the issues about how subsidies are manipulated and nepotism you have anecdotal evidence, but no significant reliable data to depend on." 27

Corruption is attributed to the weak national integrity system. The National Integrity System (NIS) is formed by the key institutions and actors which shape how a country is governed, including the executive, legislature,judiciary, and the public oversight institutions of the government, as well asnon-state actors, such as the media, civil society and the business sector.As expressed visually in the figure below where these institutions are strong and play their respective roles within the overall integrity system, transparency, accountability and integrity is firmly established and, as a consequence, corruption risks are minimal. ${ }^{28}$ Where these institutions are weak, however, corruption and other forms of governance deficits are likely to dominate the state's interactions with its citizens and the private sector, with negative consequences for sustainable development, social cohesion and economic growth.Overall, the NIS country studies find that the Egypt have very weak integrity systems, containing major gaps in legal anti-corruption provisions and showcasing an even more worrisome lack of commitment to effectiveanti-corruption practices. ${ }^{29}$ In fact, the research shows that in Egypt, it is difficult to speak of a National Integrity System, since the various governance pillars are largely isolated from one another and operate in an uncoordinated manner, without sufficient checks and balances. One problem is that of unchecked executive power that is able to interfere widely in the activities of the other branches of government and non-governmental organizations. As a consequence, the few horizontal accountability mechanisms that exist across public institutions do not function effectively. In addition, vertical accountability processes, i.e. the power of citizens to hold the powerful to account, are largely absent. Egypt still lack many democratic rights and institutions which undermine the performance of the existing formal governance institutions. ${ }^{30}$

Figure 1: A functioning National Integrity System

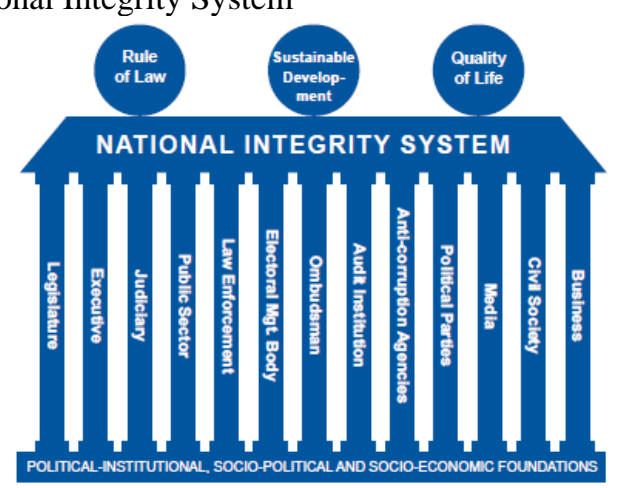

The governance systems in Egypt exhibit major defects, rendering them prone to a variety of corruption risks. Recent assessments indicate that Egypt rank as "very weak" in terms of its integrity system. ${ }^{31}$ For example, in Egypt accountability remains a significant challenge across all branches of government as well as in other social sectors, including business, the media and civil society. The NIS studies indicate some challenges whichexemplify many of the wider problems encountered throughout the MENAregion. Some of these issues are conceptual, such as limited understandingsof transparency, independence and accountability as key governance principles, while others are more tangible, such as a failure to enact laws to protectand encourage whistleblowing. ${ }^{32}$

\subsubsection{Lack of Cooperation among the pillars of the National Integrity System ${ }^{33}$}

Egypt needs for greater cooperation among the main governance stakeholders in order to strengthen the NIS as a means of facilitating good governance.As long as the relationships among political parties, as well as between the state and civil society, remain adversarial, andpublic watchdog agencies remain largely disempowered, meaningful collaboration is unlikely to materialize. ${ }^{34}$

\footnotetext{
${ }^{27}$ Ibid, p. 12

${ }^{28}$ Transparency International Report, 2010,The good governance challenge: Egypt, Lebanon, Morocco and Palestine, www.transparency.org, p.2

${ }^{29}$ Ibid, p. 3

${ }^{30}$ Ibid, p. 3

${ }^{31}$ Global Integrity, “Global Integrity Report 2007/2008”, http://report.globalintegrity.org/ [accessed 1 March 2010].

${ }^{32}$ Transparency International Report, 2010, ibid.

${ }^{33} \mathrm{Ibid}$.

${ }^{34} \mathrm{Ibid}$
} 


\subsubsection{Incomplete Integrity System - Absence of strong public watchdog agencies ${ }^{35}$}

The absence of important NIS pillars is evident upon examination of the entire National Integrity Systems in Egypt. While there arecertain institutions which can be called upon by citizens to report malpracticeby public authorities in Egypt, there is not an ombudsman institution with full powers in place. Furthermore, Egypt does not possess national anti-corruption agencies, eventhough such an agency has been proposed. ${ }^{36}$ Where public watchdogagencies do exist, they are assessed as weak and as suffering from limitedpowers and resources to play an effective role in combating corruption. ${ }^{37}$ The lack of intra-governmental checks and balances, particularly with regard to the executive, indicates the limited political will of the respective governmentsto fight corruption and is a key impediment to substantive progress. While progress has certainly been made in terms of putting corruption on the political agenda and passing some legal reforms, the actual test of whether political will exists lies in the stringent application and enforcement of these provisions in practice. There are, however, no signs that this is taking place in a systematic manner in Egypt. ${ }^{38}$

\subsubsection{Political interference in the work of public and private watchdog agencies ${ }^{39}$}

While the governments in all four countries have implemented programmes to address the roots of corruption, both public and private watchdogs are notalways free from political interference in their work. ${ }^{40}$ Political interferencecomes most often from the executive branch, which in each country studiedis able to influence many of the public oversight agencies. There are concernsthat the executive is able to use The Egyptian NIS report, for example,cites the cases of the Central Auditing Organization, whose oversight role inthe recent privatization programme has been curtailed. ${ }^{41}$ In this context, theEgyptian study also mentions a legal provision which requires consent of thepresident to begin a judicial investigation against government officials. ${ }^{42}$

\subsubsection{Limited access to public information ${ }^{43}$}

Public access to information is extremely limited across the four countries studied. Comprehensive laws on the freedom of information are missing andthose laws which do address rights to access information do not containenforcement provisions which could be used to ensure the compliance ofreluctant institutions. This lack of access to information compromises transparencyand meaningful public participation and hinders the public's abilityto uncover corrupt practices. This is particularly problematic for the media,as it restricts journalists' ability to investigate suspicions of corruption withoutencountering legal obstacles. ${ }^{44}$ In Egypt laws exist which require institutions to make certain information available; however, these laws either restrict publicaccess to this information or, as stated, lack effective enforcement mechanisms.For example, in Egypt, Law 121/1975 prohibits the independent useor publishing of official documents. ${ }^{45}$

Due to the inefficiency of the National Integrity System in Egypt, corruption prevailed and took various and enumerated forms and patterns and also different levels. Some of these forms are listed as follows:

a.

\section{Governmental interference in the economy}

One area that provides obvious opportunities for corruption is when there is extensive government interference in the economy - through imposing tariffs, paying wages and providing subsidies on basic goods.Subsidies as a potential problem however, given that subsidies are made based on a commodity, rather than being based on the user, create corruption opportunities for the suppliers of those goods. Some of these subsidies are extremely significant. For example fuel subsidies, which from a total given in subsidies of LE 136 billion, comprises LE 95 billion goes for fuel will therefore provide many opportunities for money to go astray. ${ }^{46}$ 


\section{b. $\quad$ Conflation of private and public interests ${ }^{47}$}

Conflict of interest laws are important in order to instill integrity in governmentpractices; as such laws regulate how to deal with situations where a publicofficial might also have private interests which could influence his or her publicduties. However, across the four countries, these laws are either absentor inadequate to achieve this goal. Problems concerning conflict of interestemerge in a number of NIS pillars, especially in those which are related topolitical and economic activities, such as public procurement, the businesssector and civil service.In Egypt, situations posing a conflict of interest have recently increased,particularly the emergence of prominent businesspeople that simultaneouslyhold high-level public offices. ${ }^{48}$ Moreover, across all countries studied, there is a risk ofthatconflict of interest situations can occur in those procurement contracts, whichare granted to former or current state officials, to relatives of these officialsor to a limited number of private companies which are closely linked to thegovernment. ${ }^{49}$

\section{c. $\quad$ Facilitation fees and Paying public officials ${ }^{50}$}

A second area is the payment of facilitation fees as a condition of signing contracts. One expert has said that Egypt requires foreign investors give a local business partner a 20 per cent stake in start-up ventures which gives regime figures a source of profit with little risk. ${ }^{51}$ This underlines the difficulty of ascertaining the exact nature of such transactions which are hidden even from senior officials. Samir Radwan, a former finance minister explained: "I'm out of my depth on the extent of this [problem].. We knew that it took place. We heard about the Mercedes Company paying something, but we don't have reliable and concrete information about it. It takes place for sure, from time to time you get a case blowing up and usually the investigation comes from abroad. The Mercedes case didn't come from Egypt. It was not long before the fall of Mubarak in 2010. They kept saying they would reveal the names, and these names were very high up in the system, not in the government, but who were they we don't know until now." ${ }^{52}$

Moreover, It is widely assumed that poorly-paid government officials are vulnerable to bribe taking. Petty corruption seems to be ubiquitous though under different name from, a bribe to a facilitation fee. ShereenZaky, lawyer at Shalakany Law Office, underlined the problem of assessing this accurately: "I would speculate that people who file government papers usually have to pay small bribes to get them filed. This is usually the case with any interaction with government bureaucracy. But I don't know if there are any statistics on bribery. Evidence on low-level corruption is mainly anecdotal" ${ }^{53}$ Magda Kandil, Executive Director at the Egyptian Centre for Economic Studies, said: "Yes, it's very widely perceived and I can confirm it from personal experience in dealing with government offices. Sometimes you have to resort to some type of bribe or tip just to make sure your procedure is being facilitated efficiently and swiftly." A number of interviewees made the point that there are no binding constraints or deterrent measures stipulated that can deter government employees and officials from collecting and accepting bribes, should they be offered and it can attractive for a public official to offer quality of services contingent on some type payment. ${ }^{54}$

\section{d. Public accounting systems.}

All of this is compounded by a lack of transparency in public accounting - many public bodies have a special budget line allowing them to spend funds without any transparency.There is also a lack of proper government accounting systems. There is systematic of monitoring and evaluating public spending, including investment. Egypt has a Central Auditing Organisation (CAO), but generally it does not publish its reports - they are sent directly to the president, head of parliament and prime minister who decide what to do with the information. GhadaMoussa claims that the major source of corruption lies in the: “... mis-pricing of products, raw material and land. Most corruption cases trend with natural resources and land resources. Land worth LE 10 million was sold for LE 2 million, and the LE 8 million was taken in another way. It was an oligarchic state, so that the political regime intervened with the business sector for personal interests."However, since the downfall of President Mubarak and under the last head of the CAO, their report was published for the first time. It is clear that the CAO faces structural difficulties. They sometimes fail to get the data they request from government either because the ministry doesn't want to collaborate or the government doesn't have the data. ${ }^{55}$

\footnotetext{
${ }^{47}$ Transparency International Report, 2010, ibid.

${ }^{48}$ National Integrity System Study Egypt 2009, p. 55; Global Integrity, “Global Integrity Report 2008 - Reporter's

Notebook: Egypt”, http://report.globalintegrity.org/Egypt/2008/notebook [accessed 17 March 2010]

${ }^{49}$ National Integrity System Study Egypt 2009, p. 41; IFEX, "Journalists, civil society groups call for freedom of information coalition", www.ifex.org/egypt/2009/11/27/freedom of information coalition/ [accessed 5 March 2010)

${ }^{50}$ Puddephatt, Andrew, ibid, pp. 12-15

${ }^{51}$ Inman, (2011), Mubarak family fortune could reach \$70bn, says expert, The Guardian.

${ }^{52}$ Puddephatt, Andrew, ibid, p. 13

${ }^{53}$ Ibid, p. 15

54 Ibid, pp. 15-16

${ }^{55}$ Ibid, pp.13-14
} 


\section{E. Privatization and the sale of state assets}

The sale of state-owned property and privatization is widely assumed to have been a major cause of corruption. Part of the problem here is the difficulty in accurately valuing state owned assets; land use for industries will not have the same price for land in construction and housing. This is an area that has caused much speculation among Egyptians though some observers believe there is a lot of exaggeration compounded by the lack of accurate information. Abdelfattah El-Gibaly commented: "All people speak about corruption in the privatization process based on the evaluation process of public assets. But when you evaluate assets to sell, there is a big difference in terms of the value of the asset. Some opinion said that it is corruption, true in some cases but not all the privatization process." $" 56$

With the weak national integrity system, absence of accountability and transparency and the prevalence of the different types of corruption whether petty or grand corruption, nobody can ignore the consequence, the low level of economic development. Economic underdevelopment is witnessed everywhere in Egypt. The aforementioned forms of corruption have deeply affected the different aspects of economic development in Egypt. This is clear in the poverty rates, unemployment, food insecurity, housing, healthcare and education. In the next sections, the author is going to show the negative impact of poor governance in Egypt on the previously mentioned aspects of economic development.

1.3

\section{The impact of Poor Governance on Economic development.} poverty

Poverty has risen steadily over the past two decades andnow affects over a quarter of the population. The nationalpoverty rate (the percentage of the total population whofall below the national poverty line) has increased by nearly $50 \%$ in the last 15 years, from $16.7 \%$ (9.9 million people) in1996 to $25.2 \%$ ( 21 million) in 2011. ${ }^{57}$ Thissuggests that economic growth, which was steady over thesame period, has not resulted in an improvement in the livesof ordinary Egyptians. Moreover, in 2011, a further 23.7\% of the population was just above the poverty line, puttinganother 18.9 million people at risk of poverty. ${ }^{58}$ It is therefore likely that the current political and economicinstability in Egypt has pushed the national poverty rate upsignificantly since the latest figures were published in $2011 .^{59}$

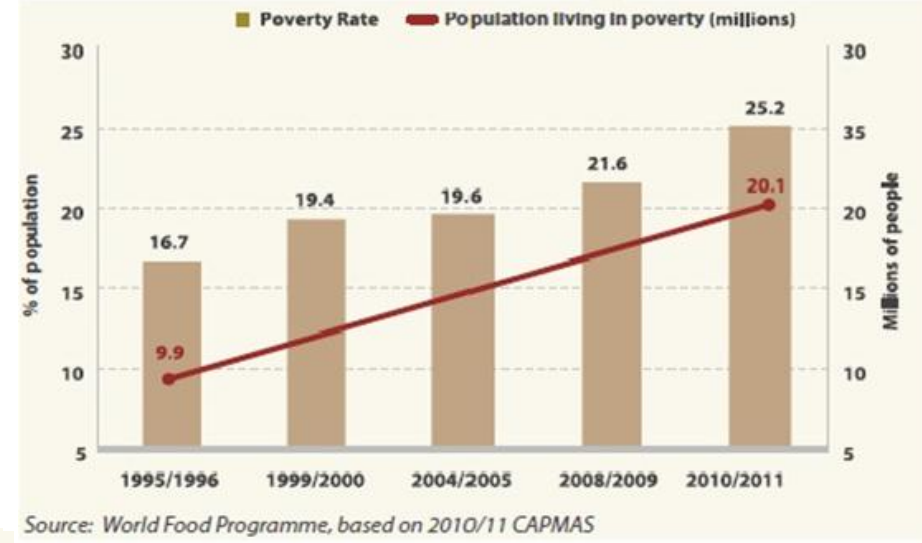

There are vast regional differences in rates of poverty.Rural Upper Egypt continues to have the highest povertyrates in the country - the poverty rate among children was $45.3 \%$ in 2009 , compared to $7.9 \%$ in urban Lower Egypt. ${ }^{60}$ The depth and severity of poverty in this region is pronounced; low educational attainment, low public investment in services such as education and health result in low capacity to generate income. At the same time, poverty in urban areas has escalated in recent years. These significant geographical variations call into question what is being done to ensure the equal enjoyment of all to the right to an adequate standard of living, without distinction as to their place of residence. ${ }^{61}$

Despite steady growth in per capita GDP, people's sense of well-being has plummeted.Low levels of popularsatisfaction have been a key factor underpinning pressuresfor reform in the Arab region.$^{62}$ In the lead

\footnotetext{
${ }^{56}$ Ibid, p. 14

${ }^{57}$, Central Agency for Public Mobilization and Statistics (CAPMAS), 2011. Household Income, Expenditure and Consumption Survey (HIECS) 2010/11

${ }^{58}$ World Economic Forum 2013, Global Competitiveness Report 2013-2014

${ }^{59}$ Egypt Factsheet No.13, Center for Economic and Social Rights, 2013.

${ }^{60}$ UNICEF 2010. Child Poverty and Disparities in Egypt: Building the Social Infrastructure for Egypt's Future

${ }^{61}$ Egypt Factsheet No.13, Center for Economic and Social Rights, ibid

${ }^{62}$ Amin, M. et al 2012. After the Spring: economic transitions in the Arab World
} 
upto the revolution in Egypt, opinion polls show that the shareof those describing themselves as 'thriving' (a combinationof current and future expectations of economic well-being)deteriorated remarkably, from $29 \%$ in 2005 to $12 \%$ in2010 (Gallup 2011). Egypt also has high rates of 'subjectivepoverty'. A third of respondents in the country's second andmiddle income quintiles described themselves as 'poor' in a2012 World Bank survey. ${ }^{63}$

\subsection{Unemployment}

One in three young people are unemployed, almostthree times the national unemployment rate. Egypt'sintergenerational inequalities are among the starkest in theregion, a factor that played a major role in the revolution.Joblessness among youth (which includes those no longerseeking work) is estimated to be $60 \%{ }^{64}$ Unemployment among university graduates standsout as particularly high; in 2010 it was $18.9 \%$, compared to $3 \%$ among those with only basic education ${ }^{65}$ Further, labor force participation rates for women in Egypt are extremely low, hovering between 20 and $25 \%$ in thelast ten years, compared to a global average of $52 \%{ }^{66}$ The unemployment rate has escalated in thewake of recent economic instability climbing from $11.9 \%$ inthe first quarter of 2011 , to $13.2 \%$ in the first quarter of $2013 .{ }^{67}$ The shortage of decent work has pushed an increasingnumber of people, especially women, into the informal sector in precarious conditions. Selfemployment, whichthe UNDP takes as a proxy for vulnerable employment,made up approximately $40 \%$ of the work force in 2007, with women increasingly falling into this category. Thiscorresponds to the ILO's calculation that $51.2 \%$ of nonagriculturalemployment in 2009 was informal. ${ }^{68}$ Stark intergenerational disparities are also apparent. In 2006the highest levels of informality were among workers aged15-24 (87.1\%), compared to those aged 25-34 (61.4\%) and35-54 (43.5\%). ${ }^{69}$ Similarly, in 2009 only $15.7 \%$ of young workers had signed a contract with their employers. ${ }^{70}$ Labor informality also sets the stage for childlabor, a bitter reality for almost 1.6 million children in Egypt. ${ }^{71}$ For much of the past decade, real wages in the privatesector have stagnated. The Egyptian economy has becomedualistic. While public sector wages have increasedin line with rising living costs, average wages in an inadequatelyregulated private sector remain virtually the sameas 10 years ago. ${ }^{72}$ Minimum wages are an importantpolicy instrument for social protection and a strongindicator of States' efforts to ensure rights at work. Egypthas yet to establish an effective system to guarantee a fairminimum wage. Though the minimum wage was recentlyincreased to 1,200 EGP, after strong lobbying from civil societygroups, it only applies to government and public sectorworkers. ${ }^{73}$

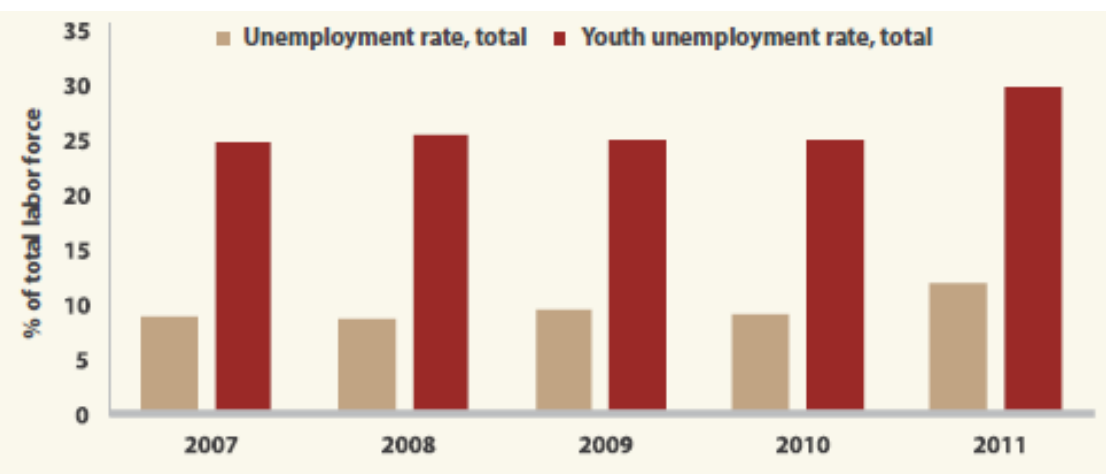

Source: CAPMAS, Indicators of social statistics.

Instead of responding to workers' demands, successive administrations have cracked down on protests, at times violently, and have restricted the right to strike.The Egyptian Center for Economic and Social Rightshas documented numerous reports of arbitrary arrestand excessive use of force against those participating instrikes and protests. Sexual assault and other forms ofviolence against women protesters has been a featureof demonstrations in Egypt. However, the State party haspersistently failed to prosecute perpetrators of these crimes. $^{74}$

\footnotetext{
${ }^{63}$ World Bank 2013. World Development Indicators

${ }^{64}$ Population Council 2009. Survey of Young People in Egypt (SYPE)

${ }^{65}$ CAPMAS, Central Agency for Public Mobilization and Statistics, 2013. Indicators of Labor and Wages

${ }^{66}$ World Bank 2012. Inclusion and resilience: the way forward for social safety nets in MENA

${ }^{67}$ CAPMAS, Central Agency for Public Mobilization and Statistics, 2013, ibid

${ }^{68}$ ILO, International Labor Organization, 2012. Statistical update on employment in the informal economy

${ }^{69}$ CAPMAS, Central Agency for Public Mobilization and Statistics, 2006. Labor Market Panel Surveys

${ }^{70}$ Egypt Factsheet No.13, Center for Economic and Social Rights, ibid

${ }^{71}$ Population Council 2009.ibid.

${ }^{72}$ CAPMAS, Central Agency for Public Mobilization and Statistics, 2013. Indicators of Labor and Wages, ibid

${ }^{73}$ Kholaif, D. 2013. 'Egypt's new minimum wage disappoints many', Al Jazeera (September 23, 2013)

${ }^{74}$ Egypt Factsheet No.13, Center for Economic and Social Rights, ibid
} 


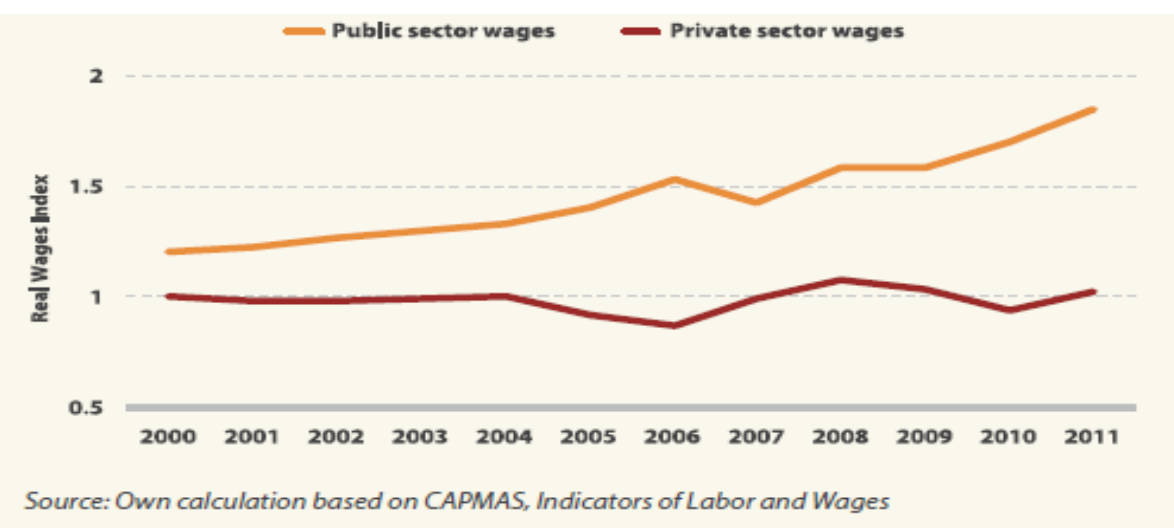

\section{$1.4 \quad$ Food Insecurity}

Poverty is being exacerbated by the sharp rise in food prices. Consumer prices for food and beverages increased by $16.3 \%$ between January 2010 and September 2013, a steeper rate than the overall consumer price index. Prices for items such as vegetables and breads and cereals have also experienced particular spikes, $21.3 \%$ and $16.3 \%$ respectively. ${ }^{75}$ This is having a serious impact on household consumption. The percentage of vulnerable households reporting that their income does not cover their monthly expenditures increased from 78.9\% in September 2011, to $88.9 \%$ in March $2013{ }^{76}$ In Qalyubia, Matrouh and Cairo this figure is even higher: $100 \%, 98.7 \%$ and $98.1 \%$ respectively. ${ }^{77}$ Similarly, in a 2012 poll conducted for the World Bank, $44 \%$ of respondents reported they could not buy the food they needed, compared to $23 \%$ in $2010 .^{78}$

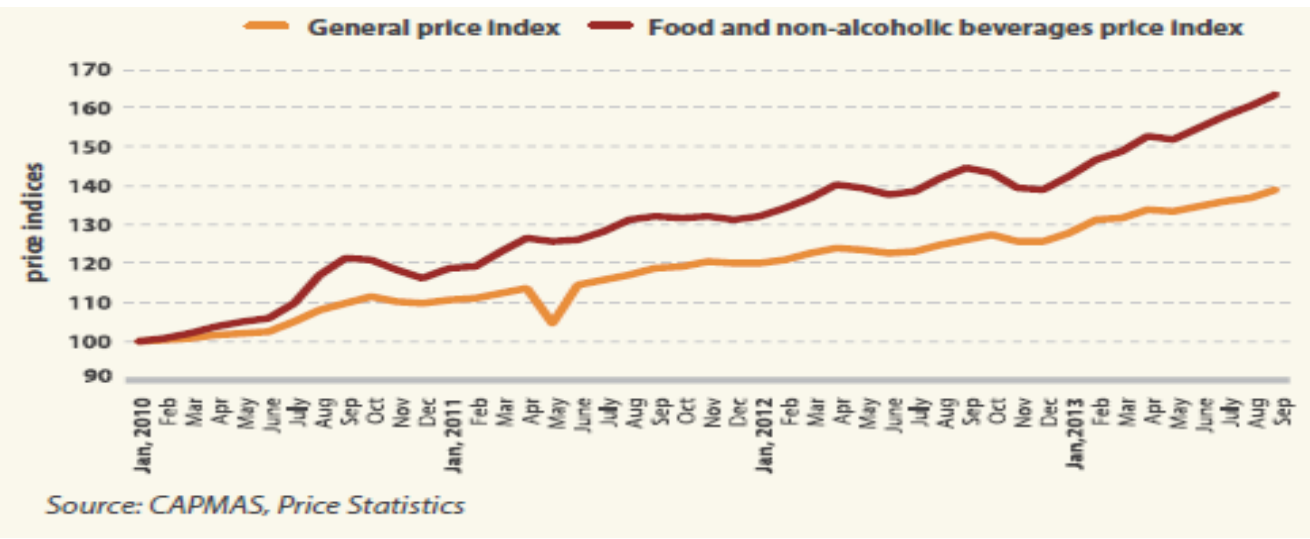

Increasing food insecurity is resulting in higher levels of malnutrition. The prevalence of food insecurity increasedfrom 14\% in 2009 to $17.2 \%$ (13.7 million people) in 2011, drivenby declining household purchasing power.$^{79}$ Foodinsecurity is highest in rural Upper Egypt, but is also becomingan increasing concern in urban areas. The rate of children underfive suffering from stunting (an indicator of chronic malnutrition)increased from $23 \%$ in 2005 to $29 \%$ in $2008 .^{80}$ and was estimated to be $31 \%$ in 2011 which is considered "high" by the WHO.Consumption of cheaper food items is the predominant copingstrategy among poorer households, leading to an increasingoverreliance on calorie-dense foods among poor households.This is to the detriment of nutritional content. The decreasingconsumption of legumes, fruits, and dairy products as a resultof Egypt's current political and economic instability is likely toexacerbate malnutrition levels even further. $^{81}$

Reforms to food subsidies must protect the right to food of vulnerable groups. The government has traditionally keptfood prices down through subsidies, which have accountedfor 1-2\% of GDP over the past decade. Two

\footnotetext{
${ }^{75}$ EFO, Egyptian Food Observatory 2013. Food Monitoring and Evaluation System: Quarterly Bulletin, Issue 11, January - March 2013

${ }^{76}$ Ibid.

${ }^{77}$ Ibid.

${ }^{78}$ World Bank 2012,ibid.

${ }^{79}$ World Food Programme 2013. The Status of Poverty and Food Insecurity in Egypt: analysis and policy recommendation, Preliminary Summary Report

${ }^{80}$ Ministry of Health and Population 2009. Egypt Demographic and Health Survey (DHS) 2008

${ }^{81}$ Egypt Factsheet No.13, Center for Economic and Social Rights, ibid
} 
thirds of thesesubsidies come in the form of subsidized bread, available toall on a first-come-first-served basis. The remainder comesin the form of ration cards that allow households to buy setquotas of commodities. Concerns about the effectiveness ofthese subsidies have prompted calls for reform. For example,almost three quarters of households covered by the ration cardsystem are not considered to be poor, while a fifth of the mostvulnerable households are excluded ${ }^{82}$ Nevertheless, the food subsidy system has a large impact on poverty. Forexample, it is estimated that in 2010/11 a further $9 \%$ of thepopulation would have fallen below the poverty line had thesesubsidies not been in place; for this reason, anyfuture reforms to the food subsidy system should safeguard therights of groups most affected by Egypt's current political andeconomic instability. ${ }^{83}$

\subsection{Housing Problem}

A pronounced shortage of affordable housing has led to a proliferation of informal settlements. Inadequateinvestment in low cost public housing and weak regulationof private developers has made the formal housing marketinaccessible for many Egyptians. Estimates of the numbers of people living in informal settlements range from $12-20$ million (up to a quarter of the population) ${ }^{84}$ These settlements suffer from a lack of facilities, amenities andproper infrastructure. Without security of tenure, their residentsare extremely vulnerable to forced eviction. Inadequate legalsafeguards give officials broad discretion to seize land for the "public interest", without any legal obligation to consult withaffected communities, as required by international humanrights standards. ${ }^{85}$

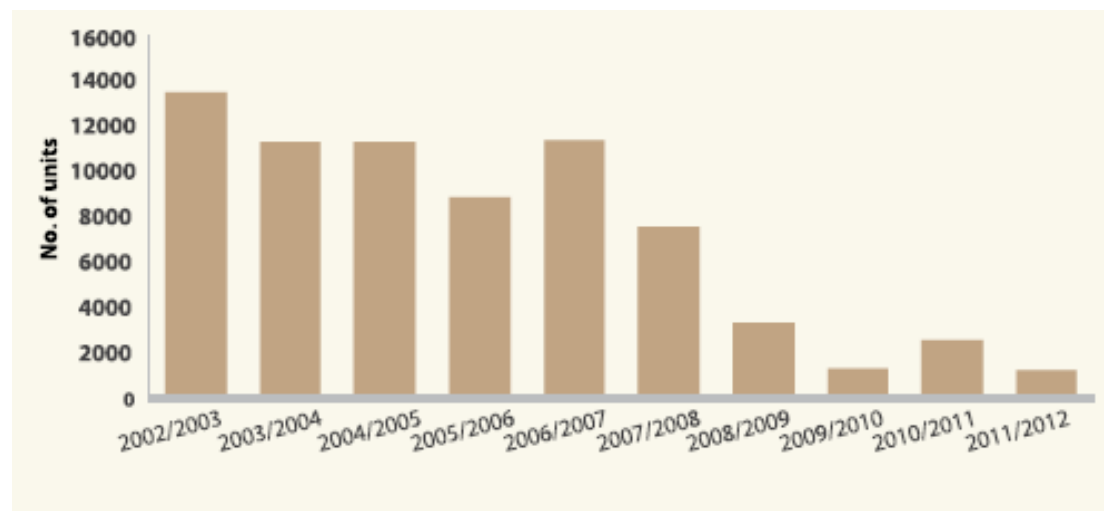

Source: CAPMAS Statistical Year Book 2013

Number of low-cost dwelling units built in urban areas, 2002/3 -2011/12

\subsection{Healthcare}

Rising costs have affected the affordability of healthcare.Egypt invests less than $5 \%$ of the total government budget inhealth; half the regional average and a third of its commitmentunder the Abuja Declaration. Low investment has led to afragmented and geographically imbalanced health care system,with people increasingly turning to private care. Just overhalf of Egyptians have health insurance, compared to 99\% inTunisia, 98\% in Iran and $83 \%$ in Jordan. ${ }^{86}$ As a result, household spending reached $72 \%$ of total health spending in 2008/09, compared to a regionalaverage of $45.4 \%$; of this, $97.7 \%$ goes to direct out-of-pocketcosts . This makeshealthcare unaffordable to many and contributes to starkdisparities in access to essential health services. There are wideurban-rural disparities in skilled birth attendance, for example, a key intervention to prevent maternal death. ${ }^{87}$

\subsection{Education}

There are serious concerns about the quality of educationin Egypt. Despite overall improvements in educationaloutcomes, less than $10 \%$ of schools meet national standards forquality education. ${ }^{88}$ The Global CompetitivenessReport for 2013-2014 ranked Egypt last out of 148 countries interms of the quality of primary education. Families have had totake on the added burden of paying for tutoring and privatelessons, which account for $42 \%$ of household spending oneducation. Investment in teachers is one way toimprove educational

\footnotetext{
${ }^{82}$ World Economic Forum 2013,ibid.

${ }^{83}$ World Food Programme 2013. The Status of Poverty and Food Insecurity in Egypt: analysis and policy recommendation, Preliminary Summary Report

${ }^{84}$ CAPMAS, Central Agency for Public Mobilization and Statistics, 2013. Statistical Year Book

${ }^{85}$ Egypt Factsheet No.13, Center for Economic and Social Rights, ibid

${ }^{86}$ Ministry of Health and Population 2010. National Health Accounts 2007/2008

${ }^{87}$ Ibid.

${ }^{88}$ UNICEF 2010. Child Poverty and Disparities in Egypt: Building the Social Infrastructure for Egypt's Future
} 
quality. Yet Egypt does not appear to beinvesting resources where these are most needed. For example,per capita spending on wages and compensation is lowest ingovernorates where the teacher-pupil ratio in primary schoolsis highest. ${ }^{89}$

\section{Conclusion}

Why the case is like this in Egypt? Why Egypt witnessed poor governance although it enacted anticorruption laws and established anticorruption agencies? The answer to this question lies in the fact that there is an implementation gap between legal reform and institutional practice. There have been a number of legislative anti-corruption reforms in Egypt which can be seen as an evidence of increased attention to the issue offighting corruption. However, a closer look reveals that many of these legislativereforms fall short of proven mechanisms to ensure accountability andtransparency. For example, Egypt's Central Auditing Organization (CAO) isresponsible for the auditing of public sector institutions and some other entities, and for producing audit reports. However, no mechanism exists to makeCAO reports available to the public, nor is an effective system in place toensure follow-up of CAO findings. Moreover, the CAO's mandate is severelylimited in that it does not address the efficiency and effectiveness of budgetexecution, or delivery of public services. Indeed, there is a critical gap between the number and quality of legal reforms on the one hand, and the actual enforcement ofthese reforms on the other. ${ }^{90}$ The weak capacity of enforcement institutionsand the limited political will to actually implement existing provisions are theprimary reasons for this 'implementation gap'. Another key challenge to effectively addressing corruption in the countries studied (as well as in the wider MENA region) is the lack of effective andwell-functioning whistleblowing mechanisms. Such mechanisms allow witnessesof corruption and other forms of malpractice to report these casesto the relevant authorities without having to fear reprisals. The protection ofthese whistleblowers from negative consequences is central to any successfulanticorruption effort, as evidenced by the prominence given to the issueof whistleblower protection in the United Nations Convention against Corruption. ${ }^{91}$ Specific provisions regarding whistleblowing or whistleblower protection are almost fully lacking across the region. While certain government agenciesmay make use of information from whistleblowers, such as the EgyptianCAO, clear procedures regulating how to report corruption and mechanismsto protect whistleblowers from retaliation are absent. Where they exist, whistleblowing laws generally regulate only a reporting mechanism. ${ }^{92}$

\section{References}

[1]. Amin, M. et al 2012. After the Spring: economic transitions in the Arab World

[2]. Bloom, D., Steven, D. \& Weston, M. (2004) Governance matters: the role of governance in Asian Economic Development. World Economics.

[3]. Burnside, C. \& Dollar, D. (1998) Aid, the incentive regime and poverty reduction.Policy Research Working Paper No. 1937. Washington, DC: World Bank.,

[4]. CAPMAS, Central Agency for Public Mobilization and Statistics, 2013. Indicators of Labor and Wages

[5]. CAPMAS, Central Agency for Public Mobilization and Statistics, 2006. Labor Market Panel Surveys

[6]. CAPMAS, Central Agency for Public Mobilization and Statistics, 2013. Statistical Year Book

[7]. CAPMAS, Central Agency for Public Mobilization and Statistics, 2011. Household Income, Expenditure and Consumption Survey (HIECS) 2010/11

[8]. Central Agency for Public Mobilization and Statistics (CAPMAS), 2011. Household Income, Expenditure and Consumption Survey (HIECS) 2010/11

[9]. Chibba, Michael, 2009, Governance and Development, The current role of theory, policy and practice, WORLD ECONOMICS Vol. $10 \cdot$ No. 2, p. 80

[10]. CIPE and Al-Ahram Centre for Political and Strategic Studies, 2009. Business Environment for Small and Medium-Sized Enterprises (SME) in Egypt and SMEs' Interaction with Government Agencies: 2009 Survey on Corruption, [online] http://www.cipe.org/sites/default/files/publication

[11]. CIPE, 2010. Egyptian Citizens' Perceptions on Transparency and Corruption

[12]. EFO, Egyptian Food Observatory 2013. Food Monitoring and Evaluation System: Quarterly Bulletin, Issue 11, January - March 2013

[13]. Egypt Factsheet No.13, Center for Economic and Social Rights, 2013.

[14]. Enterprise $\quad$ Surveys, $\quad$ Egypt, Arab Rep., http://www.enterprisesurveys.org/Data/ExploreEconomies/2008/egypt\#corruption

[15]. Global Integrity, "Global Integrity Report 2007/2008”, http://report.globalintegrity.org

[16]. Global Integrity, "Global Integrity Report 2008 Egypt”, http://report.globalintegrity.org/Egypt/2008/scorecard;

[17]. Global Integrity; “Global Integrity Report 2008 West Bank”, http://report.globalintegrity.org /West\%20Bank/2008/scorecard

[18]. Huther, J. \& Shah, A. (1998) Applying a simple measure of good governance to the debate on fiscal decentralization.Policy Research Working Paper No. 1894. Washington, DC: World Bank

\footnotetext{
${ }^{89}$ CAPMAS, Central Agency for Public Mobilization and Statistics, 2011. Household Income, Expenditure and Consumption Survey (HIECS) 2010/11

${ }^{90}$ The Global Integrity Index finds these gaps between law and practice to be large (Lebanon, Morocco, Palestine) and very large (Egypt), http://report.globalintegrity.org/ [accessed 1 March 2010].

${ }^{91}$ UNCAC, Article 33, http://www.unodc.org/unodc/en/treaties/CAC/index.html [accessed 1 March 2010]

92 National Integrity System Study Egypt 2009, ibid, p. 78
} 
[19]. IFAD,INTERNATIONAL FUND FOR AGRICULTURAL DEVELOPMENT, Executive Board - Sixty-Seventh Session, September 1999, GOOD GOVERNANCE: AN OVERVIEW.

[20]. ILO, International Labor Organization, 2012. Statistical update on employment in the informal economy

[21]. Inman, (2011), Mubarak family fortune could reach \$70bn, says expert, The Guardian.

[22]. Kaufmann, Daniel, Kraay, Aart, 2008, World Bank Research Observer Volume 23, Issue 1

[23]. Kholaif, D. 2013. 'Egypt's new minimum wage disappoints many', Al Jazeera (September 23, 2013)

[24]. Knack, S. \& Keefer, P. (1995) Institutions and economic performance: cross-country tests using alternative institutional measures. Economics and Politics, 7, 3, pp. 207-227.

[25]. Ministry of Health and Population 2009. Egypt Demographic and Health Survey (DHS) 2008

[26]. Ministry of Health and Population 2010. National Health Accounts 2007/2008

[27]. National Integrity System Study Lebanon 2009, p.14; National Integrity System Study Morocco 2009, p. 9-10;

[28]. North, D., Wallis, J. \&Weingast, B. (2008) Violence and social orders: a conceptual framework for interpreting recorded human history. Governance, Growth andDevelopment Decision-making.Washington, DC: World Bank.

[29]. OECD, 2010. Business Climate Development Strategy, Egypt: Policies for Better Business Regulation, [online] http://www.oecd.org/dataoecd/49/20/46341268.pdf

[30]. Population Council 2009. Survey of Young People in Egypt (SYPE)

[31]. Puddephatt, Andrew, (2012), Corruption in Egypt, Global Partners \& Associate

[32]. Rodrik, D. (2007) One Economics, Many Recipes: Globalization, Institutions, and Economic Growth. Princeton, NJ: Princeton University Press.

[33]. Rodrik, D. (2008) Thinking about governance. Governance, Growth and Development Decision-makingWashington, DC: World Bank.

[34]. Task Force for Financial Integrity \& Economic Development, 2011. Egypt Lost \$57.2 Billion From 2000-2008, [online] http://www.financialtaskforce.org/2011/01/26/egypt-lost-57-2-billion-from-2000-2008/

[35]. The Global Integrity Index finds these gaps between law and practice to be large (Lebanon, Morocco, Palestine) and very large (Egypt), http://report.globalintegrity.org/ [accessed 1 March 2010].

[36]. Transparency International Report, 2010, The good governance challenge: Egypt, Lebanon, Morocco and Palestine, www.transparency.org

[37]. Transparency International, 2010. Corruption Perceptions Index $2010 \quad$ Results, [online] http://www.transparency.org/policy_research/surveys_indices/cpi/2010/results

[38]. UNCAC, Article 33, http://www.unodc.org/unodc/en/treaties/CAC/index.html [accessed 1 March 2010]

[39]. UNICEF 2010. Child Poverty and Disparities in Egypt: Building the Social Infrastructure for Egypt's Future

[40]. UNICEF 2010. Child Poverty and Disparities in Egypt: Building the Social Infrastructure for Egypt's Future

[41]. United Nations Economic and Social Commission for Asia and the Pacific, What is Good Governance

[42]. World Bank (2006a) Strengthening Bank Group Engagement on Governance and Anti-Corruption, Washington, DC: World Bank (17 August).

[43]. World Bank (2006b) Press Release: World Bank Releases Largest Available Governance Data Source. Press Release No. 2009/63/WBI. Washington, DC: World Bank

[44]. World Bank (2007) Global Monitoring Report 2006. Washington, DC: World Bank.

[45]. World Bank 2012. Inclusion and resilience: the way forward for social safety nets in MENA

[46]. World Bank 2013. World Development Indicators

[47]. World Bank Report, 1992, Governance and Development

[48]. World Bank Report, 1994, Governance, The World Bank Experience.

[49]. World Economic Forum 2013, Global Competitiveness Report 2013-2014

[50]. World Food Programme 2013. The Status of Poverty and Food Insecurity in Egypt: analysis and policy recommendation, Preliminary Summary Report

[51]. World Food Programme 2013. The Status of Poverty and Food Insecurity in Egypt: analysis and policy recommendation, Preliminary Summary Report 